\title{
Rational and emotional preferred appeals of television commercials for FMCG: Evidence from young adults in Ho Chi Minh City
}

\author{
Nguyen The Khang ${ }^{1 *}$, Pham Thi Bich $\mathrm{Ngoc}^{2}$ \\ ${ }^{1}$ Ton Duc Thang University, Vietnam \\ ${ }^{2}$ Hoa Sen University, Vietnam \\ *Corresponding author: nguyenthekhang@tdt.edu.vn
}

\begin{abstract}
ARTICLE INFO
ABSTRACT

DOI: $10.46223 / \mathrm{HCMCOUJS.}$

econ.en.8.1.171.2018

Received: January $12^{\text {th }}, 2018$

This article has objectives to figure out the young adults' preferences in advertising appeals of fast-moving consumer Revised: March 27 $7^{\text {th }}, 2018$

Accepted: April 5 $5^{\text {th }}, 2018$ goods (FMCG) in Ho Chi Minh City market. The differences in rational and emotional preferences are significant between gender, age group, price segment and occupation. The finding results reflect part of Vietnamese consuming culture therefore we can come up with implications to support marketers in

Keywords:

advertising, FMCG, rational and emotional preferences, young adults finding out appropriate content for their marketing strategies. Data of this research was collected via a direct survey and analyzed by the SPSS software.
\end{abstract}

\section{Introduction}

Fast-Moving Consumer Goods (FMCG) sector, or consumer packaged goods, are usually sold quickly at a relatively low price. According to Nielsen, this industry in Vietnam is flourishing with a vital role in Vietnamese brands. For instance, in the food \& beverage segment, Vietnamese enterprises respectively occupy 69 percent and 45 percent of the market share. Due to the characteristics of fast consumption goods, this industry requires a huge frequency of running advertising in order to keep consumers' loyalty. Therefore, traditional advertising such as Printing Advertisings (print Ads) and Television Commercials (TVCs) are compulsory components to be applied by both Vietnamese and foreign companies in the FMCG market.

Together with the growth of communication in Vietnam, the advertisement industry has developed with increasing amount of quantity and the standards of quality among the participation of various foreign agencies. Besides, the market exposes many kinds of imported and local brands of FMCGs making consumers become saturated with advertising and promotion information. Therefore, the competition between each FMCGs brands in product lines, services and even in advertising has become very severe in the current business 
environment, especially when Vietnam is on the way of globalization progress. Those brands have to persuade consumers by proving that the value of their product matches with consumer insights of demand.

After Vietnam participated in WTO in 2007, many opportunities were created for multinational FMCGs companies, those came along with absolutely high prestige, reputation and experience in the global market, to enter the Vietnamese market. By launching a new business in Vietnam, one of the most vital conditions is to adapt to the culture of Vietnamese people via communication plans as well as other sales and marketing strategies (Pornpitakpan, 1999). One of the ways to get familiar with native culture is to understand their cultural values and characteristics, then behave appropriately with the native culture in a commercial environment. Any other tests or actions that run against the native cultural values are high risky experiments in marketing.

Using the table of Albers (1994), this research aims to figure out which kinds of appeals suitable for Vietnamese consumers when they expose to the advertising information. The management problem of this research is that which kinds of advertising appeals and cultural values should be used in advertising for FMCGs in order to fit with Vietnamese consumers' preference. This problem can be solved based on the concept of cultural values and by analyzing cultural dimensions. Specifically, this study will investigate rational or emotional advertising appeals fitting with young Vietnamese consumers in the case of FMCGs market. Nguyen and Le (2007) found that Vietnamese mobile phone consumers tended to purchase the product due to its information and functions rather than feeling and moods. In detail, the study set a hypothesis that FMCGs' young consumers in Ho Chi Minh City tend to prefer rational advertising than emotional advertising appeals. The preference will be different by consumers' gender, age, income and occupation.

This study focuses on young Vietnamese consumers who get information from current advertising and purchase detergent, shampoo and soap products of Unilever and $P \& G$ in the retail market. The reason is that Unilever and $P \& G$ are two biggest FMCG companies in Vietnam. Those relevant brands as Omo, Tide, Clear, Head \& Shoulder, Lifebouy, Safeguard are their typical products. Data was collected from launching online and direct surveys to consumers who have already watched TVCs and purchased FMCGs brands from supermarkets and markets in some selected districts in Ho Chi Minh City.

\section{Literature review}

\subsection{Advertising appeals from a cultural perspective}

An advertising appeal is defined as 'something that makes the product particularly attractive or interesting to the consumer' (Wells, Burnett, \& Moriarty, 1992). Security, esteem, fear, sex and sensory pleasure are examples of provided appeals by Wells et al. (1992). In 1983, Pollay provided 42 commonly usable advertising appeals. Pollay's (1983) created and developed a fulfilled list of all common advertising appeals drawn on the previous papers in advertising. That list has also been used in other previous analyses of content (Albers-Miller \& Gelb, 1996; Cheng \& Schweitzer, 1996). 
Hofstede's model of culture has been applied successfully to match cultural values with advertising appeals (Albers-Miller \& Gelb, 1996). Albers (1994) identified a number of relationships between advertising appeals by Pollay (1983) and Hofstede's dimension as presented in Table 1, this was also an attempt to conduct a test on the relationship between publicly used appeals and particular culture. The fifth dimension of long term orientation was not included in Albers' research in 1994, thus 4 out of 42 appeals by Pollay (1983) have been eliminated.

\section{Table 1}

Advertising appeals and culture dimensions

\begin{tabular}{|l|l|}
\hline \multicolumn{1}{|c|}{ Culture Dimension } & \multicolumn{1}{c|}{ Appeals } \\
\hline Individualism & $\begin{array}{l}\text { Independence: Distinctive, freedom, independencel } \\
\text { Conformity: popular, succor, family, community, affiliation } \\
\text { Power Distance high }\end{array}$ \\
Power Distance low & $\begin{array}{l}\text { Power: ornamental, dear, vain, status, health, sex } \\
\text { Submission: cheap, humility, wisdom, moral, nurture } \\
\text { Masculinity }\end{array}$ \\
Femininity & $\begin{array}{l}\text { Achievement: effective, durable, convenience, self- } \\
\text { respect, productivity }\end{array}$ \\
Uncertainty Avoidance high & $\begin{array}{l}\text { Quality of life: relax, enjoy, frail, natural, modest, plain } \\
\text { Risk aversion: safety, tamed, neat }\end{array}$ \\
Uncertainty Avoidance low & Risk-prone: casual, adventure, untamed, magic, youth \\
\hline
\end{tabular}

Source: Albers (1994)

There has been a wide range of existing literature concerning rational versus emotional advertisings (see Boyland, Harrold, Kirkham, \& Halford, 2011; Ganapatthy, 2009; Huertas \& Campomar, 2009; Khanna, 2016; X. Zhang, You, Hibino, \& Koyama, 2014). They found different results of types of appeals depending on product categories, respondents' characteristics. Khanna (2016) analyzed children's preferences in regard to appeals for the case of India and supported emotional appeals like fun and happiness, jingles and slogans, and humor. Children enjoyed looking at those ads, and these ads could create a remembering impact on their minds. Boyland et al. (2011) also found a significant impact of emotional appeals from television commercials of foods on children's interest. Similarly, X. Zhang et al. (2014) when surveying Japanese students for food ads through regression methods concluded that some emotive appeals such as interest and feeling of safety were mainly preferred. On the other hand, a Brazilian study of Huertas and Campomar (2009) on slimming drugs reinforced the effect of rational appeals as the behavioral intention was more favorable toward informational ads. In Vietnam, there are still no specific studies on how which types of appeals are preferred to young adults especially for the case of FMCGs.

\subsection{Rational advertising versus emotional advertising}

There are two drivers of emotional and rational reasons affecting consumption behavior of individuals (Albers-Miller \& Stafford, 1999). Rational advertising creates by traditional 
information-processing models of decision making in which consumers are based on logic to decide; and rely on advertised brands' persuasion and reasons about brand attributes (AlbersMiller \& Stafford, 1999). Showing the product's benefit is closely related to the self-interest of audiences (Kotler \& Armstrong, 1994). In contradiction, emotional appeals are described in the feeling or experience of buying activities that make consumers feel good about the product and brand likewise rely on feelings for effectiveness (Albers-Miller \& Stafford, 1999).

Advertising appeals can be either rationally or emotionally categorized. According to Pollay (1983), forty-two advertising appeals are categorized as emotional and rational groups in research on emotional and rational appeals in goods versus services advertising of Albers-Miller and Stafford (1999). As suggested by Lin (2001), 'Asian advertisements often contain less information than do their Western counterparts because, in a high context culture such as China, it is considered impolite to be direct or boastful. Polite communication is one who is rather indirect, modest, and vague.' Target audiences may not rely so much on prior knowledge in a low context culture like in the United States, thus advertising appeals need to include more information figuratively (Lin, 2001; Mueller, 1987).

\section{Table 2}

Advertising appeal classification

\begin{tabular}{lllc}
\hline Appeal & Rational/Emotional & Appeal & Rational/Emotional \\
\hline Effective & Rational & Durable & Rational \\
Convenient & Rational & Ornamental & Emotional \\
Cheap & Rational & Dear & Emotional \\
Distinctive & Emotional & Popular & Emotional \\
Traditional & Emotional & Modern & Rational \\
Natural & Rational & Technological & Rational \\
Wisdom & Rational & Magic & Emotional \\
Productivity & Rational & Relaxation & Emotional \\
Enjoyment & Emotional & Maturity & Emotional \\
Youth & Emotional & Safety & Rational \\
Tamed & Rational & Morality & Emotional \\
Modesty & Emotional & Humility & Emotional \\
Plain & Emotional & Frail & Emotional \\
Adventure & Emotional & Untamed & Emotional \\
Freedom & Emotional & Casual & Emotional \\
Vain & Emotional & Sexuality & Emotional \\
\hline Independence & Rational & Security & Emotional \\
Status & Emotional & Affiliation & Emotional \\
Nurturance & Emotional & Succorance & Emotional \\
& & &
\end{tabular}




\begin{tabular}{|c|c|c|c|}
\hline Appeal & Rational/Emotional & Appeal & Rational/Emotional \\
\hline Family & Emotional & Community & Emotional \\
\hline Healthy & Rational & Neat & Rational \\
\hline
\end{tabular}

Source: Pollay (1983)

\subsection{The hypothesis}

Previous researches indicated that a variety of advertising appeals sound to highlight in different cultures. Therefore, it raised an argument on whether advertising appeals preferred by Vietnamese consumers reflect the values of Vietnamese culture or not. By matching the identified culture values of the Vietnamese and the categorized advertising appeals, likewise, the high scale of young people in HCMC contributed to the energetic business environment of this city bringing high potential market of FMCGs; this argument of the study on FMCGs was assumed to the following hypothesis referring to the finding result of Vietnamese mobile phone consumers that Vietnamese people tend to purchase the product due to its information and functions rather than feeling and moods (Nguyen \& Le, 2007):

Hypothesis: FMCGs young-adult consumers in HCMC prefer a rational approach to an emotional approach.

\section{Methodological approach and data description}

\subsection{Methodological approach}

This study applied the consumer preference approach in order to test the hypotheses as previous researches successfully did in the USA, China and Hong Kong (Tai, 2004; Y. Zhang \& Gelb, 1996). A questionnaire consists of a set of questions that were designed and developed relying on 42 advertising appeals of Pollay (1983). The Likert scale with a five-point rating was tool to measure the constructed range from 1 (strongly disagree) to 5 (strongly agree) for each of the listed appeals of respondents. Respondents were asked to indicate their level of agreement or disagreement with a series of short statements on a given five-point range of responses (Bouma \& Atkinson, 1995). This approach can encourage the respondents' evaluation of the specific intention.

Young consumers aged from 17 to 35, who often used the products of Unilever or P\&G such as detergent and shampoo which are advertised by the commercial clips, were the target population of this study. Using a convenience sampling method, the questionnaire survey was accessed to the respondents at company gates, universities, and supermarkets, and online. As a result, 284 responses would be reliable enough to be used in data analysis.

Primary data was solved with the exploratory factor analysis by the software SPSS 14.0. All relevant tests and techniques have been applied as below.

Pretest and pilot study: The pilot test including essential questions to consolidate official questionnaires was built and tested on 30 people to check any respondents' misunderstanding or biases. If there were any mistakes, the questionnaire will be corrected and finalized before spreading out in actual conduction. 
Sampling method: The population is composed of millions of consumers who are buying those kinds of FMCG in Ho Chi Minh City mentioned above. According to Krejcie and Morgan (1970), with a population of over one million, the appropriate number of the sample should be over 300 samples. The sample used comes from 284 respondents.

Validity and reliability tests: According to Miyazaki and Fernandez (2000), factor analysis identified the underlying structure within a set of observed variables. Reliability was an instrument that measures and determines if comparable measures of the same construct of a given objective agree (Norusis \& SPSS Inc., 1993). A high reliable measurement would get a similar answer if it has done again by other researchers (Saunders, Lewis, \& Thornhill, 2007). Cronbach's alpha statistical analysis was an important indicator to determine the reliability of each measurement likewise this study could also get the degree to which a test is consistent and stable in measuring which it was planned to measure (Cavana, Delahaye, \& Sekaran, 2001.) The value of Cronbach's alpha greater than 0.6 was accepted and if Corrected Item-Total Correlation was lower than 0.3 , it would be dismissed (Nunnally, 1978). The higher the value of Cronbach's alpha was, the greater the reliability was.

Scales with good quality coefficient alpha were between 0.8 and 1 , scales with coefficient alpha between 0.7 and 0.8 were acceptable, and coefficient alpha between 0.6 and 0.7 indicated fair reliability (Zikmund, Babin, Carr, \& Griffin, 2010). According to Kaiser (1960), some criteria for confirmatory factor analysis are bounded with a factor loading above 0.5 , KMO (The Kaiser-Meyer-Olkin) index from 0.5 to 1 , and eigenvalue greater than 1.

\subsection{Data description}

Data was collected from 284 respondents who used those kinds of FMCG products of Unilever and $P \& G$, among them, 43 observations were excluded because of the screening questions, lack of demographic information and irresponsibly answered like choosing the same mark for all 35 main questions.

\section{Table 3}

Descriptive statistics

\begin{tabular}{|l|c|c|}
\hline \multirow{2}{*}{} & \multicolumn{2}{|c|}{ Sample: $\mathbf{n = 2 8 4}$} \\
\cline { 2 - 3 } Gender & Frequency & Percentage \\
- Male & & \\
- Female & 116 & $40.8 \%$ \\
Age group & 168 & $59.2 \%$ \\
. 17 - 25 & & \\
. 26-35 & 228 & $80.3 \%$ \\
\hline Occupation & 56 & $19.7 \%$ \\
- Students & & \\
• Non-students & 192 & $67.6 \%$ \\
Educational background & 120 & $32.4 \%$ \\
\end{tabular}




\begin{tabular}{|l|c|c|}
\hline \multirow{2}{*}{} & \multicolumn{2}{|c|}{ Sample: $\mathbf{n}=\mathbf{2 8 4}$} \\
\cline { 2 - 3 } & Frequency & Percentage \\
\hline - Primary school & 0 & $0.0 \%$ \\
- Secondary school & 2 & $0.7 \%$ \\
- High school & 11 & $3.9 \%$ \\
- University & 253 & $89.1 \%$ \\
$\quad$ - Post-graduate & 18 & $6.3 \%$ \\
Monthly income & & \\
- Below 3 million VND (Below 150 & 173 & $60.9 \%$ \\
USD) & 65 & $22.9 \%$ \\
- From 3 million to 7 million VND (150 & & $10.6 \%$ \\
- 350 USD) & 30 & $5.6 \%$ \\
- From 7 million to 10 million VND (350 & & \\
- 500 USD) & 16 & \\
- Above 10 million VND (Above 500 & & \\
USD) & &
\end{tabular}

Source: Data analysis result of the research

As can be seen from Table 3, the majority of respondents are students less than 25 years old in the collected sample of 284 young consumers in HCM city which were about 89 percent. Of this amount of sample, 80.3 percent were in the younger group (17 years old to 25 years old) and other 19.7 percent were in the older group (26 years old to 35 years old); 40.8 percent were male and 59.2 percent were female; 60.9 percent of the sample were low-end segment (with monthly income at less than US\$150); 22.9 percent belonged to the middle-end segment (US\$150-350) and 16.2 percent were the high-end segment (over US\$500).

\section{Data analysis and results}

Consumers' responses are analyzed by the methods of descriptive statistics, reliability and validity tests and independent t-test for hypotheses testing, in order to provide a comprehensive picture of Vietnamese cultural reflection in preferred advertising appeals of FMCG in the market of HCM city. The refinement process has dealt with exploratory factor analysis, joint exploratory factor analysis, rotated component matrix of the final EFA result, and sorting Cronbach's Alpha value for refined items. Those items with the factor loadings with a maximum value lower than 0.5 will be removed. Cronbach's alphas of each factor were also measured to test whether those remained items were reliable and the result showed that Independence and Risk Aversion factors had alpha that around 0.28 and 0.33 . Those factors and including items were still kept for testing the hypothesis to remain the value of this study.

After refining items through EFA and Cronbach's alpha tests, the list below stated remained items of each construct that were used to calculate and compare means of each construct in order to test hypotheses of this research. 


\section{Table 4}

Remained items after refinement

\begin{tabular}{|c|c|c|}
\hline \multirow{2}{*}{$\begin{array}{c}\text { Dimensions of each } \\
\text { Hypotheses }\end{array}$} & \multicolumn{2}{|c|}{ Remained Items } \\
\hline & Rational & Emotional \\
\hline $\begin{array}{l}\text { Individualism } \\
\text { (Independence) }\end{array}$ & & $\begin{array}{l}\text { q7-INDE1 distinctive, q23- } \\
\text { INDE2 freedom, }\end{array}$ \\
\hline Collectivism (Conformity) & & $\begin{array}{l}\text { q31-CONF2 succor, q32-CONF3 } \\
\text { family, q33-CONF4 community, } \\
\text { q29-CONF5 affiliation }\end{array}$ \\
\hline $\begin{array}{l}\text { High Power Distance } \\
\text { (Power) }\end{array}$ & q34-POW5 health & $\begin{array}{l}\text { q6-POW2 dear, q24-POW3 vain, } \\
\text { q25-POW6 sex }\end{array}$ \\
\hline $\begin{array}{l}\text { Low Power Distance } \\
\text { (Submission) }\end{array}$ & $\begin{array}{l}\text { q5-SUB1 cheap, q9-SUB2 } \\
\text { wisdom, }\end{array}$ & $\begin{array}{l}\text { q17-SUB3 moral, q30-SUB4 } \\
\text { nurturance }\end{array}$ \\
\hline Masculinity (Achievement) & $\begin{array}{l}\text { q1-ACHI1 effective, q2- } \\
\text { ACHI2 durable, q3-ACHI3 } \\
\text { convenient }\end{array}$ & \\
\hline $\begin{array}{l}\text { Femininity (Quality of } \\
\text { Life) }\end{array}$ & & $\begin{array}{l}\text { q14-QUAL2 enjoy, q20-QUAL3 } \\
\text { frail, q18-QUAL4 modest, q19- } \\
\text { QUAL5 plain }\end{array}$ \\
\hline $\begin{array}{l}\text { High Uncertainty Avoidance } \\
\text { (Risk Aversion) }\end{array}$ & $\begin{array}{l}\text { q16-RIAVE2 tamed, q35- } \\
\text { RIAVE3 neat }\end{array}$ & \\
\hline $\begin{array}{l}\text { Low Uncertainty } \\
\text { Avoidance (Risk Prone) }\end{array}$ & & $\begin{array}{l}\text { q21-RIPRO1 adventure, q22- } \\
\text { RIPRO2 untamed, q15-RIPRO4 } \\
\text { youth }\end{array}$ \\
\hline Hypothesis & $\begin{array}{l}\text { q6, q7, q14, q15, q17, q18, } \\
\text { q19, q20, q21, q22, q23, q24, } \\
\text { q25, q29, q30, q31, q32, q33 }\end{array}$ & $\mathrm{q} 1, \mathrm{q} 2, \mathrm{q} 3, \mathrm{q} 5, \mathrm{q} 9, \mathrm{q} 16, \mathrm{q} 34, \mathrm{q} 35$ \\
\hline
\end{tabular}

Source: Data analysis result of the research

\section{FMCGs consumers' preferences in HCMC:}

The paired sample T-test results led to the point that the hypothesis was supported by the data. All items related to emotional appeals and rational appeals were selected to compute the average scores for the test of the fifth hypothesis. The mean score for emotional appeals was 3.6 while the rational one was 3.72, and they were different with each other with the significant level lower than 0.05 as presented in the above, likewise, FMCG consumers in Ho Chi Minh City prefer the advertising indicating the rational or functional value of the products rather than concentrating in emotional contents. 
Table 5

Paired sample statistics of consumers' preferences on advertising appeals

\begin{tabular}{|c|c|c|c|c|c|c|}
\hline & & Mean & $\begin{array}{l}\text { Standard } \\
\text { Deviation }\end{array}$ & $\begin{array}{c}\text { Paired } \\
\text { differences } \\
\text { of the mean }\end{array}$ & $\begin{array}{l}\text { Sig. }(2- \\
\text { tailed) }\end{array}$ & $\begin{array}{c}\text { Hypothesis } \\
\text { Test }\end{array}$ \\
\hline \multirow{2}{*}{ All samples } & Emotional & 3.6025 & 0.51096 & \multirow[b]{2}{*}{-0.11889} & \multirow{2}{*}{0.000} & \multirow{2}{*}{ Supported } \\
\hline & Rational & 3.7214 & 0.54916 & & & \\
\hline \multirow{2}{*}{ Gender - Male } & Emotional & 3.6202 & 0.53658 & \multirow[b]{2}{*}{-0.05651} & \multirow[b]{2}{*}{0.191} & \multirow{2}{*}{ Rejected } \\
\hline & Rational & 3.6767 & 0.57532 & & & \\
\hline \multirow{2}{*}{ Gender - Female } & Emotional & 3.5903 & 0.49376 & \multirow[b]{2}{*}{-0.16195} & \multirow[b]{2}{*}{0.000} & \multirow{2}{*}{ Supported } \\
\hline & Rational & 3.7522 & 0.52988 & & & \\
\hline \multirow{2}{*}{$\begin{array}{l}\text { Younger } \\
\text { Consumers }\end{array}$} & Emotional & 3.6394 & 0.50809 & \multirow[b]{2}{*}{-0.14187} & \multirow[b]{2}{*}{0.000} & \multirow{2}{*}{ Supported } \\
\hline & Rational & 3.7813 & 0.51724 & & & \\
\hline \multirow{2}{*}{$\begin{array}{l}\text { Elder } \\
\text { Consumers }\end{array}$} & Emotional & 3.4524 & 0.49932 & \multirow[b]{2}{*}{-0.02530} & \multirow[b]{2}{*}{0.699} & \multirow{2}{*}{ Rejected } \\
\hline & Rational & 3.4777 & 0.61010 & & & \\
\hline \multirow{2}{*}{$\begin{array}{l}\text { Price Segment - } \\
\text { Low-End }\end{array}$} & Emotional & 3.6802 & 0.47779 & \multirow{2}{*}{-0.15149} & \multirow{2}{*}{0.000} & \multirow{2}{*}{ Supported } \\
\hline & Rational & 3.8316 & 0.51213 & & & \\
\hline \multirow{2}{*}{$\begin{array}{l}\text { Price Segment - } \\
\text { Middle-End }\end{array}$} & Emotional & 3.5692 & 0.51511 & \multirow[b]{2}{*}{-0.01923} & \multirow[b]{2}{*}{0.722} & \multirow{2}{*}{ Rejected } \\
\hline & Rational & 3.5885 & 0.51573 & & & \\
\hline \multirow{2}{*}{$\begin{array}{l}\text { Price Segment - } \\
\text { High-End }\end{array}$} & Emotional & 3.3575 & 0.55304 & \multirow[b]{2}{*}{-0.13708} & \multirow[b]{2}{*}{0.075} & \multirow{2}{*}{ Rejected } \\
\hline & Rational & 3.4946 & 0.62525 & & & \\
\hline \multirow{2}{*}{$\begin{array}{l}\text { Occupations - } \\
\text { Students }\end{array}$} & Emotional & 3.6788 & 0.47910 & \multirow[b]{2}{*}{-0.14084} & \multirow[b]{2}{*}{0.000} & \\
\hline & Rational & 3.8197 & 0.49369 & & & Supported \\
\hline Occupations - & Emotional & 3.4432 & 0.54058 & & & \\
\hline Non-students & Rational & 3.5163 & 0.60283 & -0.07307 & 0.141 & Kejected \\
\hline
\end{tabular}

Source: Data analysis result of the research

Consumers' preferences on advertising appeals grouped by age, gender, income and occupation.

The same method was conducted in order to figure out the differences between each subgroup divided by gender, age groups and price segments. The group of gender was divided to male and female groups; the younger respondents with the age at 17 to 25 years old while 
the elder groups were at the age between 26 and 35; and another subgroup was divided according to the price segment with respondents had monthly income lower than 3 million VND represented for low price segment, ones with monthly income between 3 million to 7 million VND were at the middle and the others were at the high-class segmentation. The last subgroup was divided into students and non-student groups. The final result was indicated in Table 6 below.

\section{Table 6}

Consumers' preference and cultural reflection

\begin{tabular}{|c|c|c|c|c|c|c|c|c|c|c|}
\hline & \multicolumn{9}{|c|}{ Multiple-group } \\
\hline & & \multicolumn{2}{|c|}{ Gender } & \multicolumn{2}{|c|}{ Age } & \multicolumn{3}{|c|}{ Price Segment } & \multicolumn{2}{|c|}{ Occupations } \\
\hline \multirow{2}{*}{$\begin{array}{l}\text { Rational/ } \\
\text { Emotional }\end{array}$} & $\begin{array}{l}\text { Whole } \\
\text { sample }\end{array}$ & Male & Female & $\begin{array}{l}\text { Younger } \\
(17 \sim 25)\end{array}$ & $\begin{array}{c}\text { Elder } \\
(26 \sim 35)\end{array}$ & $\begin{array}{r}\text { Low-end } \\
(<3 \mathrm{~m} / \mathrm{mth})\end{array}$ & $\begin{array}{c}\text { Middle-end } \\
(3 \mathrm{~m} \sim 7 \mathrm{~m} / \mathrm{mth})\end{array}$ & $\begin{array}{l}\text { High-end } \\
(>7 \mathrm{~m} / \mathrm{mth})\end{array}$ & Students & $\begin{array}{l}\text { Non- } \\
\text { students }\end{array}$ \\
\hline & $\checkmark$ & $\mathrm{x}$ & $\checkmark$ & $\checkmark$ & $\mathrm{x}$ & $\checkmark$ & $\mathrm{x}$ & $\mathrm{x}$ & $\checkmark$ & $\mathrm{x}$ \\
\hline
\end{tabular}

Note: $(\checkmark)=$ statistical significant difference at 0.05 level; $(x)=$ not statistically significant at 0.05 level, meant that no difference was found

Source: Data analysis result of the research

\section{Consumers' preference by gender}

According to the data, although both genders all prefer rational advertising, women also tended to prefer to be approached rationally more than male consumers with a mean score of 3.75 of rational appeals; this effect was statistically significantly supported by the data. These findings said that despite the gender of the consumers, they would make a purchasing decision to FMC for their functional needs rather than be attracted by emotional appeals communicated on television commerce. The result of data analysis was appropriate with the actual FMCG purchasing habit of Vietnamese people, they buy whenever they need to use for daily activities and the thing they care about the most are the functions and quality of those goods.

\section{Consumers' reference by age}

These findings were slightly relevant to the difference in mindset of the youth and the old. Rational appeals were preferred by both groups with a mean score of younger consumers was 3.78 higher than elders' one which surprisingly indicated that younger consumers in Ho Chi Minh city tend to be more careful to buy FMCG than the elders. The reasons to explain are that the monthly income of younger consumers is usually lower than the elders; furthermore, elder citizens purchase washing powder, soap or shampoo for their family to consume while the youth often buy for their personal needs.

\section{Consumers' preference by income}

Low-end and high-end consumers prefer to be approached rationally while there were no statistically significant differences with consumers at the middle-end segment. The subgroup of low-end consumers had a higher average preference value at 3.83 while high-end consumers mean score was 3.49 , which meant the lower class was more careful to make a purchasing decision. 


\section{Consumers' preference by occupation}

Students tend to make consuming decisions more rationally than other occupations with them mean score value of rational preference at 3.82 in comparison with the value of 3.51 of ones with other careers.

\section{Conclusion}

Vietnamese FMCG consumers in Ho Chi Minh City prefer rational advertising contents to an emotional approach, which was similar to the result of Nguyen and Le (2007). When compared via each subgroup, the Risk aversion appeals were most preferred by almost subgroups after analysis of paired sample T-tests. Additionally, all subgroup favored Submission appeals. Especially the subgroups of female and younger consumers tended to preferred Achievement appeals with the theoretical effect of Masculine culture. According to the data, the rational approach methods in television advertising were all preferred by Vietnamese FMCG consumers in Ho Chi Minh City. The rational effect was significant with female, younger consumers and low-end price segments. Totally, after conducting analysis for subgroups, the result indicated that women were found tending to have preference reflecting the values of Vietnamese culture in most of their components.

The hypothesis on rational vs. emotional approach inferred that almost Vietnamese consumers in Ho Chi Minh City prefer to be provided the technical and functional information of the products via television commerce. This practical result was familiar with Western culture because advertisements of Asia usually add more emotions, inference expression into their works rather than provide any functional comparisons in their TVC (Lin, 2001). The result of the last hypothesis of this study was also contrary to Zandpour et al.'s research on eight-country study in 1994. The supported hypothesis in this specific case of FMCG was clearly explained by the consuming needs of Vietnamese people when they need to purchase house-care products of Unilever, $\mathrm{P} \& \mathrm{G}$ or from any other companies. It could be understood that at all steps of advertising processes for FMCG product from brainstorming the ideas to running the campaigns via mass communicative media, the contents of the functional benefit of the products should be considered and participated in. Otherwise, when the market need for FMCG is stable, the emotional approach can join to increase the creativity of the advertising likewise to build up an emotional relationship with its consumers (Kotler \& Amstrong, 1994) like the 10-yearcampaign of OMO on letting children get dirty via healthy activities. In spite of its excellent emotional effect, OMO campaign always ended up with the cleaning function of this detergent powder.

Although providing information about Vietnamese consumers' preferences for advertising appeals to international and local advertisers and marketers, there were some limitations existed in this study. The majority of respondents of the whole sample are young consumers from the age of 17 to 35 years old that would affect the result of data analysis. In addition, data was collected in Ho Chi Minh City and focus on some specific products of FMCG such as detergent powder, shampoo and soap of Unilever and P\&G companies. So the expected result might be different when applying to other segments and products. 


\section{References}

Albers, N. D. (1994). Relating Hofstede's dimensions of culture to international variations in print advertisements: A comparison of appeals (Doctoral dissertation, the College of Business Administration University of Houston, Texas, USA).

Albers-Miller, N. D., \& Gelb, B. D. (1996). Business advertising appeals as a mirror of cultural dimensions: A study of eleven countries. Journal of Advertising, 25(4), 57-70. doi:10.1080/00913367.1996.10673512

Albers-Miller, N. D., \& Stafford, M. R. (1999). An international analysis of emotional and rational appeals in services vs goods advertising. Journal of Consumer Marketing, 16(1), 42-57. doi:10.1108/07363769910250769

Bouma, G. D., \& Atkinson, G. B. J. (1995). A handbook of social science research. New York, NY: Oxford University Press.

Boyland, E. J., Harrold, J. A., Kirkham, T. C., \& Halford, J. C. (2011). Persuasive techniques used in television advertisements to market foods to UK children. Appetite, 58(2), 658664. doi:10.1016/j.appet.2011.11.017

Cavana, R. Y., Delahaye, B. L., \& Sekaran, U. (2001). Applied business research: Qualitative and quantitative methods. Queensland, Australia: John Wiley \& Sons Australia, Ltd.

Cheng, H., \& Schweitzer, J. C. (1996). Cultural values reflected in Chinese and U.S. televisions commercials. Journal of Advertising Research, 36(3), 27-45.

Huertas, M. K. Z., \& Campomar, M. C. (2009). Rational and emotional appeals in advertising of prescription medicines: Study of a slimming drug in Brazil. Innovative Marketing, 5(4), 80-88.

Kaiser, H. F. (1960). The application of electronic computers to factor analysis. Educational and Psychological Measurement, 20(1), 141-151. doi:10.1177/001316446002000116

Khanna, P. (2016). A content analysis of emotional and rational appeals in selected products advertising. IRA- International Journal of Management \& Social Sciences, 4(3), 568578. doi:10.21013/jmss.v4.n3.p7

Kotler, P., \& Armstrong, G. (1994). Principles of marketing. Englewood Cliffs, NJ: Prentice Hall.

Krejcie, R. V., \& Morgan, D. W. (1970). Determining sample size for research activities. Educational and Psychological Measurement, 30(3), 607-610. doi:10.1177/001316447003000308

Lin, C. A. (2001). Cultural values reflected in Chinese and American television advertising. Journal of Advertising, 30(4), 83-94. doi:10.1080/00913367.2001.10673653

Miyazaki, A. D., \& Fernandez, A. (2000). Internet privacy and security: An examination of online retailers. Journal of Public Policy \& Marketing, 19(1), 54-61. doi: $10.2307 / 30000487$ 
Mueller, B. (1987). Reflections of culture: An analysis of Japanese and American advertising appeals. Journal of Advertising Research, 27(3), 51-59. Retrieved from https://eric.ed.gov/?id=ED271776

Nguyen, K. T. T., \& Le, H. N. (2007). Preferred appeals as a reflection of culture: Mobile phones advertising in Vietnam. Asia Pacific Business Review 13(1), 21-39. doi:10.1080/13602380600652987

Norusis, M. J., \& SPSS Inc. (1993). SPSS for windows base system Users guide. Englewood Cliffs, NJ: Prentice Hall.

Nunnally, J. C. (1978). Psychometric theory (2nd ed.). New York, NY: McGraw-Hill.

Pollay, R. W. (1983). Measuring the cultural values manifest in advertising. In J. H. Leigh, \& C. R. Martin Jr. (Eds.), Current issues and research in advertising (pp. 72-92). Ann Arbor, MI: University of Michigan.

Pornpitakpan, C. (1999). The effect of cultural adaptation on business relationships: American selling to Japanese and Thais. Journal of International Business Studies, 30(2), 317-337.

Saunders, M., Lewis, P., \& Thornhill, A. (2007). Research methods for business students. London, UK: Prentice Hall.

Tai, H. C. S. (2004). The relationship of cultural values and message strategies in service advertising. Marketing Intelligence \& Planning, 22(4), 438-454. doi:10.1108/02634500410542798

Wells, W. D., Burnett, J. \& Moriarty, S. (1992). Advertising: Principles and practice. Englewood Cliffs, NJ: Prentice Hall.

Zandpour, F., Campos, V., Catalano, J., Chang, C., Cho, D. Y. \& Jiang, S.-F. (1994). Global reach and local touch: Achieving cultural fitness in TV advertising. Journal of Advertising Research, 34(5), 35-63.

Zhang, X., You, Z., Hibino, H., \& Koyama, S. (2014). Contribution of food commercials' informational/emotional appeals to Japanese consumer attitude and purchase intention. International Journal of Affective Engineering, 13(1), 43-50. doi:10.5057/ijae.13.43

Zhang, Y., \& Gelb, B. D. (1996). Matching advertising appeals to culture: the influence of products' use conditions. Journal of Advertising, 25(3), 29-46. doi:10.1080/00913367.1996.10673505

Zikmund, W. G., Babin, B. J., Carr, J. C., \& Griffin, M. (2010). Business research methods (8th ed.). Cincinnati, OH: South-Western College Pub. 